\section{Violence against indigenous children and adolescents in Venezuela}

\author{
Violencia contra niños y adolescentes indígenas \\ en Venezuela
}

\author{
Violência contra crianças e adolescentes \\ indígenas na Venezuela
}

Roberto Briceño-León 1

Gloria Perdomo 1,2

doi: 10.1590/0102-311X00084718

\begin{abstract}
Research on violence in indigenous communities refers to traditional practices of competition for scarce goods and clashes with other populations over their territories. Violence against children is not described, and authors of some studies state a tradition of good treatment towards them. In our study we shows that the situation has changed and new forms of violence are affecting 725,000 inhabitants from 51 indigenous groups of Venezuela, especially those composed of children and adolescents. The method used was interviews with key informants and for secondary census, civil society data and journalists' reports. Results describe the existence of four types of violence: (a) structural violence, derived from the shortage of food and medicines that have caused deaths due to malnutrition and lack of medical attention, prostitution, girl trafficking and forced emigration; (b) violence of organized crime, which exercise control of illegal mining and affect the Yanomami and Pemón peoples, as workforce for the production of coca and drug trafficking with the Yupka people; and contraband of gasoline in the Wayúu people; (c) domestic violence due to cultural changes derived from new patterns of alcohol consumption or the use of physical punishment of children between Piaroa and Yekuana peoples; and (d) the illegal violence of the State for the imposition of mining with the Pemón people or the repression for the protests with the Warao and Inga peoples. In the article we show the great difference between the official discourse of protection of indigenous peoples and the realities of violence, criminal exploitation and violation of rights suffered by indigenous children and adolescents.
\end{abstract}

South American Indians; Child; Adolescent; Violence; Human Rights

\author{
Correspondence \\ R. Briceño-León \\ Laboratorio de Ciencias Sociales, Universidad Central de \\ Venezuela. \\ Calle A. Codazzi, Quinta LACSO, Santa Mónica, Caracas / \\ DC - 1040, Venezuela. \\ roberto.bricenoleon@gmail.com \\ 1 Laboratorio de Ciencias Sociales, Universidad Central de \\ Venezuela, Caracas, Venezuela. \\ 2 Universidad Católica Andrés Bello, Caracas, Venezuela.
}




\section{Introduction}

Violence against indigenous children and adolescents has undergone a major transformation at the beginning of the 21 st century in Venezuela. The traditional violence that could occur within indigenous communities or social violence between indigenous communities and neighboring nonindigenous populations have been modified to enable new modes linked to the humanitarian crisis, organized crime and State violence.

Violence among indigenous populations of Venezuela has been the subject of studies whose authors have highlighted the relevance of violence for the constitution of social order in these communities 1 . Whereas there is agreement on the relevance that violence has in some groups, such as Yanomami in Amazon, there is no agreement on the explanation of the social function that it performs. For some authors this violence shows conflicts that, from the perspective of sociobiology, emerge from the competition for access to women and that may, in its turn, generate mechanisms of cooperation between men in such a way marriage alliances are made after the war 2 . For others, from the ecological point of view, it refers to the search for proteins and, therefore, competition for access to meat and hunting 3 , and for third parties, such as Lizot 4 , it is an internal logic of social action, linked to cosmology and a mechanism to promote exchange and reciprocity.

In the Yupka people, located between Venezuela and Colombia, two types of violence are known, one dedicated to external warfare, through which they attack non-Yupka enemies (Yupo) and capture their women and children, to then integrate them into their communities. In this type of violence aggressors have prestige, in such a way their violent actions are praised and sung in their celebrations. But there is another type of violence, which is internal and linked to revenge or duels within the group, resulting from adultery, for example, and which does not generate prestige and, therefore, is silenced.

Halbmayer 5 argues that the distinction between legal or illegal violence does not exist among the Yupka, neither in societies lacking a legal system. In these cases, violence is a response to the real or symbolic suffered aggression, it is the exercise of a negative reciprocity. Difference between legitimate and illegitimate violence is subjective, therefore, it will always be legitimate by the person who commits it, and it will be illegitimate for those who suffer it, victims or some witnesses 6 .

In the Wayuu population, which lives in a semidesert region of Goajira, on the Colombian-Venezuelan border, violence has been linked to conflicts over natural resources, such as water, pastoral lands or salt pans as well as cattle theft 7 . In this town, conflict resolution mechanisms outstand, since they can be violent, of violent negative reciprocity, or material compensation for the suffered deaths or injuries ${ }^{8}$. This normative construction, with its roles and an intermediary, called pütchipüü, in Wayuu or palabrero, in Spanish, seeks to achieve consensus and compensation between victims and victimizers. This propensity to mediate through word is also found in the correction of children who have behaved improperly, or in relationships between children and adolescents within the community.

These different conceptions about the use of nature's goods, the dignity of the person or the application of justice, as well as the conflicts derived from the occupation of indigenous territories, have caused a second type of violence with non-indigenous people.

This scenario has changed in the new century due to the presence of other forms of violence that equally affect the population nowadays: (a) structural violence, which refers to the living conditions of the population that subject them to poverty, hunger, malnutrition or abandonment by the State 9 ; (b) violence of organized crime, expressed in the actions of criminal groups who systematically seek economic benefits and can have various forms in illegal mining, drugs, guerrillas and murders 10; (c) family violence, resulting from changes in traditional parenting patterns in which the proximity of the mother, father and immediate family members in the teaching of obedience and good behaviors was appreciated, thus favoring the predominance of a good coexistence in the communities and, when there were fights, were disapproved by norms and practices of social control in charge of the families 11 . With the influence of other cultures and the deterioration of living conditions, violent practices are incorporated for the upbringing and punishment of children, and situations of violence between family members and communities are evident; and, finally, (d) illegitimate violence of the State, when people are illegally attacked, with actions of the army to evict them from their lands by legal mining (coal), or to repress smuggling allegations that are made by the army itself. 
The objective of our article is to describe these four types of violence, to identify their origins and to analyze their impact on the living conditions of the indigenous populations, in particular on their children and adolescents.

\section{Methods}

Knowledge of violence against indigenous children and adolescents is restricted by the absence of official information. Since 2003, the Venezuelan government has censored information on violence and crimes, data of subsequent years were not published and the data of the previous ones were deleted from the websites of official organisms.

In Venezuela, not only is information on indigenous peoples precarious, as it also occurs in other countries of Latin America, but there has been a decade of political will to censor information on health, crime, economy and social rights.

In this study we used primary and secondary sources. The primary sources consisted of 23 open interviews conducted with key informants linked to indigenous communities: teachers, security personnel, religious entities (priests and nuns), nongovernmental organization personnel, and human rights activists, which were selected based on opinion.

Secondary sources involved the Indigenous Census, conducted every ten years, which in 1982 included only speakers of an indigenous language, but, in 2001 and 2011, criteria of self-recognition were used 12. Victimization studies that have been carried out in the country 13; the Living Conditions Survey (ENCOVI, in Spanish) with national coverage and multistage stratified sampling of 2016 and 2017 14; and the annual reports of the Venezuelan Observatory of Violence in 2016 and 2017, which uses an information triangulation methodology based on (a) daily collection of information on crimes and violent events that appear in written and digital press; (b) unpublished data from police files; and (c) studies and reports from universities and human rights organizations 15 . The methodology is based on the concept of "crimes known to society", instead of the traditional "crimes known to the police" 16.

Although the study we conducted does not qualify as "medical research on human beings", we adopted the Declaration of Helsinki regulations, promulgated by the World Medical Association (WMA) in all that is relevant, being clear that the main purpose of this study is to promote respect and protection of the dignity and rights of children and adolescents of indigenous populations, a crucial issue to ensure the ethics of this research.

Among the main precautions and care was to protect the anonymity and privacy of the people who contributed information and opinions. The key informants consulted in this study were selected through a non-random sampling procedure, in which expert professionals and local leaders identified people who were familiar with the social situation of the indigenous communities. These informants participated voluntarily, knew the purposes and scope of the study, and expressed their consent to provide opinions and knowledge about the situations of violence they had experienced or observed. The Venezuelan legislation does not include an Ethics Committee to report on the procedure followed in social investigations.

\section{Results}

According to results of the 2011 census, the indigenous population of Venezuela is composed of 724,592 people, representing $2.7 \%$ of the total population (Table 1). This population was distributed in 51 indigenous peoples or ethnic groups, of which 42 were originally from the country and 9 were foreigners 17 . Twelve of those 51 ethnic groups represented $90 \%$ of the indigenous population, being the Wayuu the majority with 413,000 people representing $61 \%$ of the total indigenous population. The state with the largest indigenous population is Zulia, where the Wayuu population lives; however, it represents only $12 \%$ of the total. On the other hand, the Amazonas state has the highest percentage of indigenous population, with 76,000 people representing half (52\%) of its population (Table 2 ). 
Table 1

Indigenous population pert sex and age group. Venezuela, 2011.

\begin{tabular}{lllll}
\hline Age group (years) & Male & Female & Total & $\%$ \\
\hline $0-4$ & 47,714 & 45,117 & 92,831 & 12.8 \\
$5-9$ & 44,515 & 42,691 & 87,206 & 12.0 \\
$10-14$ & 44,532 & 42,327 & 86,859 & 11.9 \\
$15-19$ & 40,408 & 40,550 & 80,958 & 11.2 \\
$\geq 20$ & 188,407 & 188,331 & 376,738 & 52.0 \\
Total & 365,576 & 359,016 & 724,592 & 100.0 \\
\hline
\end{tabular}

Source: National Statistical Office of Venezuela, 2014.

Table 2

Population per declaration of belonging to an indigenous group according to a federal entity. Venezuela, 2011.

\begin{tabular}{|c|c|c|c|c|}
\hline State & Indigenous & Non-indigenous & Total & $\begin{array}{c}\% \text { indigenous } \\
\text { population }\end{array}$ \\
\hline Amazonas & 76,314 & 70,166 & 146,480 & 52.1 \\
\hline Delta Amacuro & 41,543 & 123,982 & 165,525 & 25.1 \\
\hline Zulia & 443,544 & $3,260.860$ & $3,704.404$ & 12.0 \\
\hline Bolívar & 54,686 & $1,358.429$ & $1,413.115$ & 3.9 \\
\hline Apure & 11,659 & 447,466 & 459,025 & 2.5 \\
\hline Sucre & 22,213 & 874,078 & 896,291 & 2.5 \\
\hline Anzoátegui & 33,848 & $1,435.699$ & $1,469.747$ & 2.3 \\
\hline Monagas & 17,898 & 887,545 & 905,443 & 2.0 \\
\hline Nueva Esparta & 2,200 & 489,410 & 491,610 & 0.4 \\
\hline Lara & 2,112 & $1,772.755$ & $1,774.867$ & 0.1 \\
\hline Other states & 18,675 & $15,782.748$ & $15,801.423$ & 0.1 \\
\hline Total & 724,592 & $26,503.338$ & $27,227.930$ & 2.7 \\
\hline
\end{tabular}

Source: National Statistical Office of Venezuela, 2014.

The indigenous population is a young population, half of the population $(47,1 \%)$ is under 20 years of age and those under 15 years represent $36.8 \%$ of its population (Table 1), much higher than the country where that group of age represents $27 \%$, a decrease of ten percentage points 17 .

A surprising aspect is that the majority of the indigenous population of Venezuela lives in urban areas of the country (Table 3). A total of 63\% live in cities or their surroundings. Population living in rural areas represents $36 \%$, being $10 \%$ of the indigenous people who only speak their own language. Half of the indigenous people are bilingual, and a third, 33\%, although declaring themselves to be indigenous, only speak Spanish 17.

The Venezuelan rate of violent deaths in 2017 was 89.8 per 100,000 inhabitants 15 . Venezuela is the country with the highest homicide rate in the Americas, well above El Salvador (54), Colombia (32), Brazil (29) and Mexico (18) 18.

Young people consist in the victims of violence ${ }^{19}$. In 2016, 15.9\% of homicide victims were under 19 years of age. Among them, 0.8\% aged between 10 and 14 years old, and 14.6\%, between 15 and 19 years. There are more men than women, and the difference increases as the victims' age increases (Table 4). The homicide rate between people aging 10 and 14 years of age was 4.9 per 100,000 inhabitants, whereas the rate for adolescents aged from 15 to 19 years was 91 per 100,000 inhabitants. 


\section{Table 3}

Indigenous population per rural-urban area, according to a federal entity. Venezuela, 2011.

\begin{tabular}{lcccc}
\hline State & Urban & Rural & Total & \% rural \\
\hline Amazonas & 22,799 & 53,515 & 76,314 & 70.1 \\
Anzoátegui & 12,346 & 21,502 & 33,848 & 63.5 \\
Apure & 1,611 & 9,948 & 11,559 & 86.1 \\
Bolívar & 10,991 & 43,695 & 54,686 & 79.9 \\
Delta Amacuro & 5,309 & 36,234 & 41,543 & 87.2 \\
Lara & 1,261 & 851 & 2,112 & 40.3 \\
Monagas & 5,832 & 12,066 & 17,898 & 67.4 \\
Nueva Esparta & 2,180 & 20 & 2,200 & 0.9 \\
Sucre & 13,132 & 9,081 & 22,213 & 40.9 \\
Zulia & 366,371 & 77,173 & 443,544 & 17.4 \\
Other states & 16,387 & 2,288 & 18,675 & 12.3 \\
Total & 458,219 & 266,373 & 724,592 & 36.7 \\
\hline
\end{tabular}

Source: National Statistical Office of Venezuela, 2014.

Table 4

Homicides of children and adolescents per age group and sex. Venezuela, 2016.

\begin{tabular}{|c|c|c|c|c|c|}
\hline \multirow[t]{2}{*}{ Age groups (years) } & \multicolumn{3}{|c|}{ Victim's sex } & \multicolumn{2}{|c|}{ Total } \\
\hline & Female & Male & Undefined & $\mathbf{n}$ & $\%$ \\
\hline $0-4$ & 34 & 39 & 2 & 75 & 0.43 \\
\hline $5-9$ & 7 & 18 & 0 & 25 & 0.14 \\
\hline $10-14$ & 25 & 113 & 0 & 138 & 0.80 \\
\hline $15-19$ & 113 & 2,379 & 1 & 2,493 & 14.61 \\
\hline $20-24$ & 114 & 4,228 & 1 & 4,343 & 25.46 \\
\hline$\geq 25$ & 528 & 9,448 & 7 & 9,983 & 58.53 \\
\hline Total & 821 & 16,225 & 11 & 17,057 & 99.97 \\
\hline
\end{tabular}

Source: Venezuelan Observatory of Violence, 2017.

With the available numbers we cannot discriminate between ethnic groups; however, there are some associations we can use as a reference. The Amazonas state, whose population is $52.1 \%$ indigenous peoples, featured a rate of 96.8 homicides per 100,000 inhabitants. The Delta Amacuro state, whose population is composed of $25 \%$ indigenous population, mainly of the Warao ethnic group, featured a homicide rate of 38.4; and the Zulia state, with the largest indigenous population, the Wayuu, featured a rate of 38.1 homicides per 100,000 inhabitants 15 .

\section{Structural violence}

The Venezuelan economy prospered during most of the 20th century due to the exportation of oil, first achieved by foreign companies and, since 1975, after nationalization, by a national State industry. In 1999, when Hugo Chávez assumed the presidency, the price of a barrel of oil was an average of USD 10; one year later it reached USD 120, creating a great boom that allowed the government to increase imports, expropriate and break the national private industry, in order to strengthen the power of the State and the civic-military government. 
However, in 2014 oil prices suddenly dropped, the production declined, and the country did not have the resources to continue importing food, medicines, goods and services that it had been doing for a decade, in addition to lacking the capacity to borrow such. To maintain itself in power, the government proceeded to liquidate assets and make money without support, causing the highest inflation in the world. Between 2014 and 2018, the Venezuelan economy was reduced by 45\%. In 2012, the country had 23 kilos of average meat consumption per person, and in 2107 it dropped to 4 kilos of meat per inhabitant 20 .

At the beginning of 2018 , this situation caused a social situation they described as a "complex humanitarian emergency", characterized by hunger, acute shortage of medicines and the inability of the State to face shortages, epidemics and to provide assistance due to sick people 21. The ENCOVI showed that poverty had increased from $48.4 \%$ in 2014 to $87 \%$ in 2017 , of which $61.2 \%$ could not obtain the necessary basic foodstuffs 14 . This situation has affected the most vulnerable populations, constituting structural violence.

In 2017, Caritas conducted a nutritional study on the indigenous communities of the state of Zulia, and found chronic malnutrition in children under five years of age. In Delta Amacuro, the lack of food became so serious for the indigenous people that, in 2016, members of different Warao communities were forced to feed only on mangoes for two months, since there was no food supply in the area and they could not travel to other places to obtain them, due to lack of public transport or gasoline for their boats 22 . At the beginning of 2018, two Warao Indians, aged 19 and 25, died after consuming food in the municipal garbage dump, in Tucupita, in Delta Amacuro state. Doctors from the Luis Razetti Hospital in Tucupita diagnosed that they died from poisoning caused by the consumption of bitter cassava 23 .

In addition to the lack of food, they have suffered from lack of vaccines and medicines. In March 2018, a total of 28 Warao children died in the municipalities of Tucupita, Pedernales and Antonio Díaz del Delta Amacuro 24. The Venezuelan Society of Public Health estimates, according to data from the Pan American Health Organization (PAHO) from July 2017 to February 2018, that the country accumulated 886 confirmed cases of measles and 2,891 suspected cases, for which the country concentrates $80 \%$ of confirmed cases in America 25.

The situation is similar with other communicable diseases. According to the PAHO, cases of malaria in Venezuela, which represented 2.5\% of patients in the region in 2015, accounted for 30.2\%, in 2016, and increased to $48.1 \%$ in 2017 of all cases of malaria in the Americas 26. At the beginning of 2018, in San Juan de Manapiare, Amazonas state, in an operation of the Brazilian Ministry of Health, 690 people were diagnosed with malaria, and among them 10 pregnant women died due to the disease 27 .

Authors of some studies showed that the Warao population living in the Orinoco River Delta has been suffering from an epidemic of HIV-1 subtype B that in 2013 had reached $35 \%$ of men, and it was estimated that it doubled every year ${ }^{28}$. Nonresponse and no provision of treatment to patients led to the death of almost all men in that community, leading to the isolation of women and to increase in the number of orphaned children, in addition to adolescents having no one to marry or being rejected, since, according to the symbolic representation of the disease, they are believed to be haunted, thus breaking the family life.

This situation of structural violence has forced indigenous populations to emigrate and abandon their lands within the Venezuelan territory, and to move to neighboring countries such as Brazil and Colombia. Between 2014 and 2015, the presence of 532 Warao Indians was reported in the city of Boa Vista, in Roraima state, Brazil. In May 2017, nearly 400 Waraos were registered in the city of Manaus, in the Amazonas state, who had left Venezuela due to hunger. In 2018, due to the increase of emigrants, the Brazilian army has installed shelters to receive migrants and some shelters have been especially built to attend indigenous peoples and their families. On the border of Venezuela with Colombia, the situation of poverty and scarcity has led the Wayúu population to migrate to the Colombian side. Similarly, Yupka Indians from Sierra de Perijá, in Venezuela, have settled in the public spaces of Cúcuta, in Colombia, along with thousands of other Venezuelans fleeing from the country 29.

Information on infant and maternal mortality has been censored in Venezuela. The last published Yearbook of Mortality corresponds to the year 2013, and weekly epidemiological bulletins were suspended in 2104. When in 2016, the Minister of Health, Antonieta Carporale, published the delayed 
bulletins featuring that infant mortality had increased $30 \%$ in relation to the previous year, and maternal mortality, 65.6\%. The Minister was dismissed when she had just four months in office 30 .

\section{Violence of organized crime}

Indigenous communities live in isolated areas of the country where there is a very precarious presence of the state. This geographical isolation facilitates territorial control by groups of organized crime, which displace indigenous authorities and replace the state in their functions to facilitate illegal business: mining, drugs and gasoline smuggling.

\section{- Violence in mining}

The mining exploitation in Venezuela that affects the indigenous populations is concentrated in the Bolívar state, where gold, bauxite, coltan and diamonds are exploited, and in the Zulia state where there is coal production. The indigenous population has participated in the mining activity, doing their own exploitation work in an artisanal way or cooperating with some of the small independent producers. This relationship became conflictive due to the presence of wildcat miners who exploit in the open and with significant environmental damage. Subsequently, there were conflicts with large transnational companies, and recently with the decision of the national government to create and deliver to the army a large area of mineral exploitation known as the "Mining Arc", which occupies $111,000 \mathrm{~km}^{2}$, the equivalent to $12 \%$ of the country, a territory greater than that of Portugal $\left(92,000 \mathrm{~km}^{2}\right)$ or Panama $\left(77,000 \mathrm{~km}^{2}\right)$, and in which $7.5 \%$ of the indigenous population lives 31 .

There is a history of clashes with indigenous populations in this mining area. In 1993 there was a massacre of 16 Yanomami people in the community of Hasimú; in 2005, miners attacked a Yanomami community from a helicopter, killing women and children. In recent years, this situation has changed because individual actors were replaced with armed groups 32 .

Violence is imposed by two main ways: the dispossession of the lands, as it occurs with the Pemón Indians in Ikabarú, whose lands have been given to the Mining Arc for gold, bauxite and dolomite exploitation 33; and exploitation, as a workforce of children and adolescents in the tasks of auxiliary work or domestic services and prostitution. Human-rights organizations have denounced the presence of indigenous adolescents in the brothels in the mines, called currutelas. In these cases, exploitation and violence has been facilitated, since many of them do not have national identification documents 34 . Other researchers and activists of indigenous peoples' rights have denounced the kidnapping of Yekuana girls in Manapiare, in Venezuela, and the exploitation of Warao girls moved from their territories to be prostituted, which adds the crime of human trafficking to the crimes of sexual abuse and exploitation 35 .

In Zulia state, coal mines are located on Yupka lands, which have opposed the exploitation of the mineral by a company owned by the government of Venezuela for the contamination and damage it causes to the environment, in addition to conflicts over livestock, and caused the murder of indigenous people.

\section{- Violence in the drug business}

Venezuela is not a country that produces illegal drugs, but it is a very important transit country. It is estimated that $41 \%$ of cocaine seized in Europe and 51\% of shipments intercepted by ships in the Atlantic had their origin in Venezuela 36. This circumstance can be clearly observed in the territory of the Yupka population, who are forced to work in the production of coca paste that the guerrilla group National Liberation Army (ELN, in Spanish) controls on the Colombian side of the Sierra de Perija, and use young people and Yupka children as soldiers 37 and for the transportation of the drug by the rivers towards the lake of Maracaibo, in the Venezuelan territory; from there, the bands send caches worldwide 38 . The two border municipalities where the drug circulates, the Jesús María Semprúm and Catatumbo, had in 2017 rates of 176 and 115 homicides per 100,000 inhabitants 15,39. 


\section{- Violence and gasoline smuggling}

The price of gasoline in Venezuela is practically zero. In April 2018, with the American dollar sold on the black market, one driver could buy more than 500,000 liters of gasoline. These conditions are a powerful incentive for the smuggling of gasoline to neighboring countries.

Organized crime, in its different forms, controls the smuggling business to Colombia and Brazil. Oil trucks of 36,000 liters, which cost less than USD 1 in Venezuela, can sell between USD 10,000 and 15,000 in Colombia. In order to control smuggling, in 2003 the government of Venezuela handed over the border gasoline business to eleven Wayuu cooperatives (called Ayatawacoop), but later, the indigenous leadership of that cooperative was displaced and the guerrilla ELN group took control of the cooperative. Small-scale smuggling occurs with gasoline extracted from private vehicles. Wayuu children are employed for performing both the operation of sucking the gasoline from the vehicles and placing them in small containers, the pimpinas, and then moving it to Colombia. Faced with the situation of widespread poverty in the country, schools in the area report that children drop out of school to devote themselves to this business and help their families 40 .

\section{Family violence}

Family violence among indigenous populations occurs in several forms, as follows.

\section{- Physical violence}

Forms of domestic violence in indigenous communities may vary among different ethnic groups. Although specialists believe that children were highly respected, almost sacred. Authors of an anthropological study 41 dedicated to know the patterns of upbringing of the Yekuana, Wayuu, Piaroa, Añú, Jivi and Warao report a peaceful, non-conflictive coexistence in these communities, where a tradition of respect seemed established, opposing to the fights or hostile behavior, or the use of physical violence in parenting. Concerning cultures, such as the Piaroa, they reported that "children and adults did not fight much because there was fear that the offended could ask a sorcerer to harm the offender" 41 ( $\mathrm{p}$. 167); this same study documents the change in behavior among children and adolescents, product of the exchange with the "Criollos" culture 41. Practices of physical punishment of parents for correcting children is explained by transculturation processes that younger generations have experienced in their contact with the Western culture ${ }^{42}$.

\section{- School and violence}

The indigenous adolescent population that wishes to pursue studies must move to educational centers located in the nearest cities. For young people this causes several changes, because they must adapt to the urban life, urban youth groups and the lyceum. Since they have few economic resources, urban insertion takes place in the poorest areas of the city where they can find a place to live and study. In these areas there is an urban subculture marked by the territorial control of youth gangs, who exercise violence as a means to prevail and gain respect from the population and its adversaries. Therefore, the process of socialization occurs not with the Western culture, but with the juvenile culture of the favela, with its urban music, the game of dominoes and gambling, and also with urban drugs, alcohol and violence component, which they would take with them to return to their communities of origin.

\section{- Alcohol consumption and violence}

Reports of violence towards women or children after festivities are related to change in the pattern of alcohol consumption in indigenous communities. The traditional pattern was low consumption during the year, reduced to festivities and certain privileged individuals, but the change of chicha, a drink made by indigenous peoples, for the consumption of beer or rum, abundantly and throughout the year, has generated a situation of violence in the family due to interfamily aggression and dispute over the use of family resources for alcohol consumption 43 


\section{- Sexual violence}

Another component of family violence has been a traditional practice of exchanging women as a way to establish alliances and social relationships. Some authors consider, from the feminist perspective, that this is related to the predominance of patriarchy within these groups 44 . However, this traditional practice, possibly linked to the rules of exogamy, has acquired a different form with the delivery of girls and adolescents to provide sexual services to mining or military neighbors, and is increasing girls and adolescents trafficking and the forced prostitution business with the parents' endorsement.

\section{The illegal violence of the State}

The illegal violence of the State is linked to disputes over the control of access to natural resources, social control and the application of extrajudicial punishments and is manifested in various forms as follows.

\section{- Violence and access to land}

The illegal violence of the State has been expressed in conflicts over the demarcation of indigenous lands. The national government granted indigenous people lands that were occupied by cattle ranches owned by nonindigenous people. In that process, the government had to pay compensation to the owners, in such a way that they could later grant the land and benefactions to the indigenous people. Since the government did not compensate, a situation of violence was generated by the protest of both sectors that had led to the death of several leaders. The most prominent case was the cacique Sabino Romero, who after being eighteen months in prison, was released by the courts and a few months later was killed in an ambush where his wife and newborn son were also wounded 45.

\section{- Violence and access to mines}

Another type of violence has occurred because of the dispute with military forces over the control of mines for the exploitation of gold. Since 2011, the government has nationalized the exploitation of gold, prohibiting the mining activity of indigenous peoples on their lands. Indigenous communities continue with artisanal exploitation and have reported that they are prohibited, although such activity is allowed to others. That was the case of the Tonoro mine, in Angostura municipality, in Mexico, where a group of more than 100 indigenous people disarmed and detained 22 soldiers whom they accused of guarding a gold deposit that they exploited for their own benefit. Two years later, in Urimán, municipality of Gran Sabana, in Venezuela, Indians held 43 soldiers hostage to demand for them to be allowed to carry out small-scale mining and the arrival of airplanes with food and fuel, which was being banned by the military commander of the area. These actions, of course, entailed a response from military and paramilitary groups, generating deaths and disappearances of people from the communities 46 .

\section{- Violence and access to food}

The scarcity of food in the country was accentuated in 2016 and 2017. The government controlled the sale of food under a rationing that limited the days and the quantity of products, and forced to report identity, through fingerprints, in the trade to be able to make purchases. In September 2017, the Jakonevese community was unable to buy food for over a month, and they carried out a protest that was suppressed by shots fired by the National Guard, resulting in the deaths of two young Warao and the wounding of five more people 47. 


\section{- The extrajudicial violence of the police}

Finally, there is a violence that the state applies to the so-called People's Liberation Operations (OLP - Operación de Liberación del Pueblo, in Spanish) in poor populations since 2015, aiming at repressing crime, and which has resulted in the killing of thousands of young people executed by the military or police in an action that the Attorney General of the Republic described as "extermination" 48,49. These military operations attack a territory and leave after a few hours, having destruction and death in the area as a consequence. This has struck mainly in poor urban areas, but also in areas of indigenous population, such as the Inga (Putumayo) population of the Amazon, where the OLP have attacked families and seized their property without judicial procedure.

\section{Discussion}

Children and adolescents from indigenous populations in all periods have been subjected to the worst life conditions by territorial exclusion. These conditions have been aggravated by the collapse caused by the rentist and statist economic policies of the Venezuelan government.

This violence affects indigenous children and adolescents who live in the city or in suburban areas. Since most indigenous populations live in urban areas, they are exposed to the same violence as other urban inhabitants, only perhaps in conditions of greater vulnerability. In these conditions, the exchange with the criollos, instead of promoting mutual enrichment, has promoted a coexistence based on hostility and aggression characteristic of urban violence.

In rural areas, governmental decisions to promote mining exploitation in areas of natural reserve where these people traditionally lived brought to these localities the presence of Mafias dedicated to the extraction of minerals, irregular armed groups, and organized crime groups that have caused serious social problems and brought drugs, violence and death. The devastation in these territories has deepened the poverty and lack of food of the ethnic groups, subjected to extreme deprivation, against which there is no public institution that guarantees the rights to life, health care, food and education of children and adolescents.

The response of the State, instead of promoting protection and rule of law, has been militarization and the incorporation of officials into the zone, who have been denounced for acts of corruption, association with criminal groups, and for committing serious human-rights violations.

To the traditional violence that has existed towards indigenous populations in Venezuela, as well as in other countries of Latin America, new types of violence and oppression are added nowadays, in addition to the traditional abuses of the landowners, the violence of the new political elite, of new owners of the lands and mines. Moreover, we can mention the urban violence learned in the shantytowns added to the rural violence, and the violence of military officials added to the violence of criminal gangs.

The Social State of Law and Justice does not exist or provide any protection to populations in these circumstances. Although this situation has been denounced by international organizations, such as the Inter-American Commission on Human Rights (IACHR) 50,51 and PAHO 52, the seriousness of the problem has not been acknowledged, nor a response by the national government.

These realities contrast with the rules of integral protection for indigenous peoples enshrined in the Constitution of the Republic, in the Covenants and other international human rights treaties, and in the special laws in force in the country for the safekeeping, protection and social development of the indigenous population within the country and, especially, of the children and adolescents of the ethnic groups that inhabit the Venezuelan territory.

Despite the official discourse of the government, which tends to promote greater protection of the original communities of the country, the results of the so-called Bolivarian revolution have been that of a greater social vulnerability, the alteration of their living environments, an increase in communicable diseases and unprecedented violence against children and adolescents in indigenous communities. 


\section{Contributors}

R. Briceño-León was in charge of the design of the study and the article. Both authors equally contributed to the research and writing.

\section{Additional informations}

ORCID: Roberto Briceño-León (0000-0002-8882-

7787); Gloria Perdomo (0000-0001-6352-8193).

\section{Acknowledgments}

The study on which this article is based was supported by the Konrad Adenauer Stiftung.

\section{References}

1. Alès C. Violence et ordre social dans une société amazonienne. Les Yanomami du Venezuela. Études Rurales 1984; (95-96):89-114.

2. Macfarlan SJ, Walker RS, Flinn MV, Chagnon NA. Lethal coalitionary aggression and long-term alliance formation among Yanomamö men. Proc Natl Acad Sci U S A 2014; 111:16662-9.

3. Harris M. Animal capture and Yanomamö warfare: retrospect and new evidence. J Anthropol Res 1984; 40:183-201.

4. Lizot J. À propos de la guerre [Une réponse à N. A. Chagnon]. J Soc Am 1989; 75:91-113.

5. Halbmayer E. Socio-cosmological context and forms of violence: war,vendetta,duels and suicide among Yupka of north-western Venezuela. In: Schmidt BE, Schroder IW, editors. Anthropology of violence and conflict. London: Routledge; 2001. p. 49-75.

6. Riches D. The anthropology of violence. Oxford: Basil Blackwell; 1986.

7. Benson S. Los Wayú (Guajiro). In: Coppens W, Escalante B, Lizot J, editors. Los aborigenes de Venezuela. v. III. Caracas: Fundación La Salle de Ciencias Naturales/Monte Avila Editores; 1988. p. 25-145.

8. Perrin M, Machado JU. La Ley Guajira: justicia y venganza entre los Guajiros. Revista CENIPEC 1985; 9:83-118.

9. Farmer P. An anthropology of structural violence. Curr Anthropol 2004; 45:305-23.

10. Briceño-León R. Pandillas, mafias y bandas: una visión sociologica del delito organizado. In: Briceño-León R, Camardiel A, editors. Delito organizado, mercados ilegales y democracia en Venezuela. Caracas: Alfa; 2015. p. 15-38.

11. Amodio E. Pautas de crianza de los pueblos indígenas de Venezuela Jivi, Piaroa, Ye'kuana, Añú, Wayuu y Warao. Caracas: Fondo de las Naciones Unidas para la Infancia; 2005.

12. Allais M. La población indígena de Venezuela según los Censos Nacionales. In: II Conferencia Nacional de Demógrafos y Estudiosos de la Población. Caracas: Universidad Católica Andrés Bello; 2004. p. 1-19.
13. Instituto Nacional de Estadística. Encuesta Nacional de Victimización y Percepción de la Seguridad Ciudadana. Caracas: Instituto $\mathrm{Na}-$ cional de Estadística; 2010.

14. Universidad Católica Andrés Bello; Universidad Central de Venezuela; Universidad Simón Bolívar. Encuesta de Condiciones de Vida 2017. Caracas: Universidad Católica Andrés Bello; 2018.

15. Observatorio Venezolano de Violencia. Informe Anual de Violencia 2017. Caracas: Observatorio Venezolano de Violencia; 2017.

16. Camardiel A, Avila O. Un marco metodologico del Observatorio Venezolano de Violencia. In: Briceño-León R, Avila O, editors. Violencia en Venezuela. Caracas: Laboratorio de Ciencias Sociales; 2007. p. 107-34.

17. Instituto Nacional de Estadística. Informe Final - Censo Nacional 2011. Caracas: Instituto Nacional de Estadística; 2011.

18. Clavel T. InSight Crime's 2017 homicide round-up. https://www.insightcrime.org/ news/analysis/2017-homicide-round-up/ (accessed on 16/Feb/2018).

19. Chacón A, Fernandez J. El impacto de la violencia en niños, niñas y adolescentes. Caracas: Cecodap; 2013.

20. Barrios D, Santos MA. Venezuela: anatomia de un colapso. Boston: Center for International Development, Harvard University; n.d.

21. Fraser B, Willer H. Venezuela: aid needed to ease health crisis. Lancet 2016; 388:947-9.

22. Recamier M. Los venezolanos más vulnerables. Reporte Indigo 2018; 14 feb. https:// www.reporteindigo.com/latitud/los-venezo lanos-vulnerables-crisis-derechos-humanosdemocracia-economia/.

23. Fuentes L. Mueren dos indígenas waraos por consumir yuca amarga en un basurero de Tucupita. El Cooperante 2018; 23 ene. https:// elcooperante.com/mueren-dos-indigenaswaraos-por-consumir-yuca-amarga-en-unbasurero-de-tucupita/. 
24. Kapé-Kapé. Radiografía del paso del sarampión por Delta Amacuro. https://kape-kape. org/2018/04/01/radiografia-del-paso-del-sa rampion-por-delta-amacuro/ (accessed on 05/ Abr/2018).

25. The collapse of the Venezuelan health system. Lancet 2018; 388:1331.

26. Pan American Health Organization. Increase of malaria in the Americas. Washington DC: Pan American Health Organization; 2018.

27. Franquis B. La mortalidad materna por malaria y desnutrición aumentó en indígenas. El Nacional 2018; 15 mar. http://www.elnacional.com/noticias/sociedad/mortalidadmaterna-por-malaria-desnutricion-aumentoindigenas_226931.

28. Villalba JA, Bello G, Maes M, Sulbaran YF, Garzaro D, Loureiro CL, et al. HIV-1 epidemic in Warao Amerindians from Venezuela: spatial phylodynamics and epidemiological patterns. AIDS 2013; 27:1783-91.

29. International Crisis Group. Cómo detener la onda expansiva de la crisis en Venezuela. Brussels: International Crisis Group; 2018. (Report, 65).

30. El gobierno de Venezuela destituye a la ministra de Salud, Antonieta Caporale, luego de que se difundieran cifras sobre el aumento de mortalidad materna e infantil. BBC News 2017; 12 may. http://www.bbc.com/mundo/noticiasamerica-latina-39892614.

31. Programa Venezolano de Educación-Acción en Derechos Humanos. Informe sobre el Arco Minero del Orinoco a la Comisión Interamericana de Derechos Humanos. Caracas: Programa Venezolano de Educación-Acción en Derechos Humanos; 2016.

32. Mikkelsen C. El mundo indígena 2012. Copehangen: International Work Group for Indigenous Affairs; 2012.

33. Aporrea.org. Comunicado: solidaridad con el pueblo Pemón, fuera el crimen organizado de los territorios indígenas. Aporrea.org 2018; 3 apr. https://www.aporrea.org/actualidad/ n323106.html.

34. Moncada Acosta A. Oro, sexo y poder: violencia contra las mujeres indígenas en los contextos mineros de la frontera Amazónica Colombo-Venezolana. Textos \& Debates 2018; (31):43-53.

35. Vitti M. Historias de warao: Arco Minero del Orinoco, una nueva amenaza. Revista SIC 2016; 17 jul. http://revistasic.gumilla. org/2016/historias-de-warao-arco-minerodel-orinoco-una-nueva-amenaza/.

36. United Nations Office on Drugs and Crime. Informe mundial sobre las drogas 2015. Vienna: United Nations Office on Drugs and Crime; 2015.

37. Machado JE. Reclutamiento de niños por grupos armados en la frontera colombo-venezolana. Caracas: UCAB Ediciones; 2016.

38. Weir J. Humano derecho. Runrun.es 2016; 25 sep. http://runrun.es/relax/280528/humanoderecho-con-jose-quintero-weir.html.
39. Jiménez D. El drama de los narco-indígenas. Vértice 2016; 7 jul. https://vertice.news/ el-drama-de-los-narco-ind\%C3\%Adgenas4 be9cca791d6.

40. Hernandez A. En La Guajira venezolana, los niños abandonan la escuela para vender gasolina. The New York Times 2017; 9 feb. https:// www.nytimes.com/es/2017/02/09/en-laguajira-venezolana-los-ninos-abandonan-laescuela-para-vender-gasolina/amp/.

41. Amodio E, Perez G, Poblete C. Las pautas de crianza del pueblo Piaroa de Venezuela. Caracas: Fondo de las Naciones Unidas para la Infancia; 2006.

42. Montenegro R, Stephens C. Indigenous health in Latin America and the Caribbean. Lancet 2006; 367:1859-69.

43. Seale JP, Shellenberger S, Rodriguez C, Seale JD, Alvarado M. Alcohol use and cultural change in an indegenous population: a case study from Venezuela. Alcohol Alcohol 2002; 37:603-9.

44. Fernandez J. Mujeres y niñas indígenas: doblemente discriminadas. Anmistía Internacional - Blog 2017; 11 aug. https://www.amnistia. org/ve/blog/2017/08/3355/mujeres-indige nas.

45. Sociedad Homo et Natura. Sabino. Aporrea. org 2016; 2 aug. https://www.aporrea.org/ ddhh/a231768.html.

46. Arias A. Comunidades Pemón rechazan con contundencia la militarización y el hostigamiento. Aporrea.org 2018; 10 feb. https:// www.aporrea.org/desalambrar/a159140.html.

47. Aporrea.org. 2 jóvenes waraos fueron asesinados durante represión contra protesta por comida en Tucupita. Aporrea.org 2017; 25 sep. https://www.aporrea.org/actualidad/ n314993.html.

48. Ministerio Público. Actuaciones del Ministerio Público relacionadas con las OLP en Venezuela. Caracas: Ministerio Público; 2017.

49. Ministerio Público. Informe anual de gestión 2016. Caracas: Ministerio Público; 2017.

50. Comisión Interamericana de Derechos Humanos. Informe anual 2016. Capitulo IV-B. Venezuela. Washington DC: Comisión Interamericana de Derechos Humanos; 2016.

51. Comisión Interamericana de Derechos Humanos. Las mujeres indígenas y sus derechos humanos en las Américas. Washington DC: Comisión Interamericana de Derechos Humanos; 2017.

52. Organización Panamericana de la Salud. Respuesta de la OPS para mantener una agenda eficaz de cooperación técnica en Venezuela y los Estados miembros vecinos. Washington DC: Organización Panamericana de la Salud; 2018. 


\section{Resumen}

La investigación sobre la violencia en las comunidades indígenas se refiere a las prácticas tradicionales de competencia por los bienes escasos $y$ enfrentamientos con otras poblaciones por sus territorios. La violencia contra los niños no se ha conocido, y algunos estudios afirman la existencia de una tradición de buen trato hacia ellos. Este estudio muestra que la situación cambió y que nuevas formas de violencia están afectando a 725.000 habitantes de los 51 grupos indígenas de Venezuela, especialmente niños y adolescentes. El método utilizado fue entrevistas con informantes clave, un censo secundario, así como datos de la sociedad civil e informes de periodistas. Los resultados describen la existencia de cuatro tipos de violencia: (a) violencia estructural, derivada de la escasez de comida y medicinas, que ha causado muertes debido a la malnutrición y falta de atención médica; prostitución, tráfico de niñas y emigración forzosa; (b) la violencia del crimen organizado, que ejerce el control de la minería ilegal y afecta a los Yanomami y Pemón, como fuerza de trabajo para la producción de coca y tráfico de drogas en el caso de los Yupka; además de contrabando de gasolina con los Wayúu; (c) la violencia doméstica, debido a los cambios culturales, derivada de nuevos patrones de consumo de alcohol o la aplicación del castigo físico de niños entre los Piaroa y Yekuana; y (d) la violencia ilegal del estado para la imposición de la minería con los Pemón o la represión de las protestas con los Warao e Inga. El artículo expone la gran diferencia entre el discurso oficial de protección a los indígenas y las realidades de violencia, explotación criminal y violación de los derechos sufridos por los niños y adolescentes indígenas.

Indios Sudamericanos; Niño; Adolescente; Violencia; Derechos Humanos

\section{Resumo}

A pesquisa sobre violência em comunidades indigenas se refere a práticas tradicionais de disputa por bens escassos e confrontos com outras populações pela posse de seus territórios. A violência contra crianças ainda não foi descrita, e alguns estudos afirmam uma tradição de bom tratamento em relação a elas. $O$ estudo mostra que a situação já mudou, e que novas formas de violência estão afetando 725.000 habitantes de 51 grupos indigenas na Venezuela, especialmente contra crianças $e$ adolescentes. O método utilizado teve como base entrevistas com informantes-chave e acesso a dados censitários e de fontes da sociedade civil, além de relatos de jornalistas. Os resultados descrevem a existência de quatro tipos violência: (a) violência estrutural, derivada da escassez de alimentos e medicamentos, que provoca mortes devido à desnutrição e à falta de atendimento médico; prostituição e tráfico de meninas, além de emigração forçada; (b) violência praticada pelo crime organizado, com o controle da mineração ilegal e que afeta os povos Yanomami e Pemón, como força de trabalho na produção de coca e no tráfico de drogas no povo Yupka e o contrabando de gasolina no povo Wayúu; (c) violência doméstica em função de mudanças culturais derivadas dos novos padrões de consumo de álcool ou do uso de castigo físico de crianças, entre os povos Piaroa e Yekuana; $e$ (d) violência ilegal praticada pelo estado pela imposição da mineração no povo Pemón ou com a repressão de protestos pelos povos Warao e Inga. $O$ artigo mostra a grande diferença entre o discurso oficial da proteção dos indígenas e a realidade de violência, exploração criminosa e violação dos direitos das crianças e adolescentes indígenas na Venezuela.

Índios Sul-Americanos; Criança; Adolescente; Violência; Direitos Humanos
Submitted on 28/Apr/2018

Final version resubmitted on 29/Aug/2018

Approved on 15/Oct/2018 